\title{
Simultaneous Den Use by Arctic Foxes and Wolves at a Den Site in Nunavut, Canada
}

\author{
CHRISTOPHER J. HENDRICKSON, ${ }^{1}$ GUSTAF SAMELIUS, ${ }^{1,2}$ RAY T. ALISAUSKAS ${ }^{1,3}$ and SERGE LARIVIÈRE ${ }^{1,4}$
}

(Received 28 March 2005; accepted in revised form 4 May 2005)

\begin{abstract}
Arctic foxes (Alopex lagopus) and wolves (Canis lupus) often use similar den sites. Interspecific interactions and competition for den sites are therefore possible among these species. At the Kangowan River in Nunavut, Canada, we observed arctic foxes and wolves simultaneously using a den site for pup-rearing during a two-day period in the summer of 2000. We also found evidence that both species had used the den site in May that year. Interspecific interactions in summer included avoidance, tolerance, and aggression. Foxes and wolves used separate entrances and did not appear to share a common space. Our observations of arctic foxes and wolves occupying a den site concurrently suggest that avoidance and interspecific tolerance may have facilitated coexistence at this den site.
\end{abstract}

Key words: den use, interspecific interactions, coexistence, Alopex lagopus, Canis lupus

RÉSUMÉ. Les renards arctiques (Alopex lagopus) et les loups (Canis lupus) s'installent souvent dans des tanières du même genre. Par conséquent, il est possible que chez ces espèces, il y ait des interactions inter-espèces et une certaine concurrence pour l'obtention des tanières. À la rivière Kangowan, dans le Nunavut, au Canada, on a observé des renards arctiques et des loups qui se servaient simultanément d'une tanière pour élever leurs petits pendant une période de deux jours à l'été 2000. On a également trouvé des preuves que ces deux espèces s'étaient servies de la tanière au mois de mai de cette même année. L'été, les interactions inter-espèces prenaient la forme de l'évitement, de la tolérance et de l'agression. Les renards et les loups empruntaient des entrées différentes et ne donnaient pas l'impression de partager des lieux communs. Par ailleurs, nos observations des renards arctiques et des loups qui occupent une même tanière en même temps laissent croire que l'évitement et la tolérance inter-espèces pourraient avoir joué un rôle dans la coexistence à cette tanière.

Mots clés: tanière, interactions inter-espèces, coexistence, Alopex lagopus, Canis lupus

Traduit pour la revue Arctic par Nicole Giguère.

\section{INTRODUCTION}

Interspecific interactions among canid species vary significantly, ranging from avoidance and tolerance to aggression and predation (Palomares and Caro, 1999; Linnell and Strand, 2000). The theory of interspecific interactions predicts that dominant predators typically eliminate smaller subordinate predators through either aggression or predation (Palomares and Caro, 1999; Linnell and Strand, 2000). However, tolerant interactions between predators may facilitate coexistence (Linnell and Strand, 2000).

Interactions between arctic foxes (Alopex lagopus) and wolves (Canis lupus) are poorly described, yet both species use similar den sites. Arctic foxes prefer to use dens excavated in sandy, well-drained substrate for parturition and pup-rearing (Audet et al., 2002). Wolves also use dens excavated in earth and are known to use and modify dens of other animals, including those of foxes, for parturition and pup-rearing (Carbyn and Paquet, 2003). Thus, similarities in den use by these two species may result in interspecific competition for den sites. Here we report on an observation of arctic foxes and wolves concurrently using a den site for pup-rearing in the summer of 2000.

\section{STUDY AREA AND METHODS}

Our observations were made at the Kangowan River $\left(67^{\circ} 12^{\prime} \mathrm{N}, 100^{\circ} 32^{\prime} \mathrm{W}\right)$ in the Queen Maud Gulf Bird Sanctuary (QMGBS), Nunavut, Canada, in the spring and summer of 2000. The Kangowan River lies within the central Arctic lowland, which consists of gently rolling tundra dominated by rock outcrops, drumlins, sedge meadows, and marshes, interrupted by shallow tundra ponds and lakes (Ryder, 1972). The QMGBS is the largest bird sanctuary in the world, and it is an important nesting ground for numerous migratory birds, especially waterfowl (Kerbes, 1994). Other carnivores present in the area

\footnotetext{
${ }^{1}$ Department of Biology, University of Saskatchewan, 112 Science Place, Saskatoon, Saskatchewan S7N 5E2, Canada

${ }^{2}$ Corresponding author: gustaf.samelius@ec.gc.ca

${ }^{3}$ Canadian Wildlife Service, 115 Perimeter Road, Saskatoon, Saskatchewan S7N 0X4, Canada

${ }^{4}$ Delta Waterfowl Foundation, R.R.\#1, Box 1, Portage La Prairie, Manitoba R1N 3A1, Canada; present address: Cree Hunters and

Trappers Income Security Board, Edifice Champlain, Bureau 1100, 2700 Blvd Laurier, Sainte-Foy, Quebec G1V 4K5, Canada

(C) The Arctic Institute of North America
} 
included grizzly bears (Ursus arctos), wolverines (Gulo gulo), and short-tailed weasels (Mustela erminea). Observations were made with a spotting scope from a distance of ca $300 \mathrm{~m}$ and were part of a study on arctic fox ecology.

\section{RESULTS}

We observed two adult wolves with two pups and two adult arctic foxes with at least nine pups using a den site at Kangowan River concurrently from 4 to 6 July 2000. We recorded a total of 20 entrances at the den site on 5 July, of which six were large entrances (ca $0.5 \mathrm{~m}$ in diameter). Wolf pup activity was concentrated around one large entrance, whereas fox pup activity was scattered among other entrances of the den site. We did not observe wolf pups and fox pups on top of the den at the same time. The entrance with wolf pup activity was $3 \mathrm{~m}$ away from the closest entrance with fox pup activity. On 9-10 July, arctic foxes were still present at the den site; we did not observe any wolves, however, and we suspect that the wolves had moved their pups to another location. We observed evidence of both species having used the den site on 17 May, when two entrances were open: one small foxsized entrance (ca $0.15-0.2 \mathrm{~m}$ in diameter) and another larger entrance (ca $0.5 \mathrm{~m}$ in diameter). There were also fresh wolf tracks, one fresh wolf scat, fresh fox tracks, and fresh fox scats at the den site.

On 6 July at 00:08, we observed an adult wolf at the den site. An adult arctic fox followed the wolf, barking and biting at its hind legs, apparently attempting to draw the wolf away from the den site. The wolf in turn chased the fox for a distance of about $100 \mathrm{~m}$. Wolves otherwise appeared tolerant of foxes. At 00:12, a female wolf (enlarged teats) approached the den site with the first wolf, while the adult fox ran out of sight. When the female wolf approached the large entrance where we had previously observed activity by wolf pups, two wolf pups emerged and began suckling the female at the entrance. Wolf pups suckled for five minutes until the female wolf detected the observer and moved a few hundred meters away from the den site. She returned to the den site at 01:00. After the female wolf had left the den site, one adult arctic fox was seen watching the den from about $200 \mathrm{~m}$ away while the wolf pups explored around the large entrance. Adult arctic foxes appeared cautious and tended to avoid the large entrance with wolf pup activity both before and after these interactions. We saw no aggressive interactions between adult foxes and wolf pups.

\section{DISCUSSION}

Arctic foxes and wolves often use similar den sites (Audet et al., 2002; Carbyn and Paquet, 2003). To our knowledge, however, simultaneous use of a den site by arctic foxes and wolves has not been documented previously.
Wolves and arctic foxes used the den site at Kangowan River simultaneously for at least two days. Moreover, there was also sufficient wolf and fox activity in the spring to suggest use for parturition by both species. However, the extent to which each species used this den site during spring and summer is not known. We suspect that foxes would probably not risk predation of their pups by relocating them to a den site where wolves were already raising their pups. This conclusion follows observations that red foxes (Vulpes vulpes) avoid raising pups in areas where coyotes (Canis latrans) travel and raise pups (Voigt and Earle, 1983; Sargent et al., 1987). Similarly, Tannerfeldt et al. (2002) found that arctic foxes avoid breeding in the vicinity of red foxes and that their young suffer greater risk of depredation the closer they are to red fox dens. Thus, we question the potential of wolves and arctic foxes to use a den site for parturition and pup-rearing concurrently for nearly two months.

Given the size advantage of wolves, one might expect them to kill, exclude, or cause avoidance behaviour in arctic foxes. Instead, wolves at the den site at Kangowan River appeared tolerant of foxes, except when chasing the fox that bit one of the wolves. Similar tolerance by coyotes and wolves towards red foxes has been observed (Sargeant and Allen, 1989; Peterson, 1995). Wolves generally move their pups from natal dens to rendezvous sites when pups are 6-10 weeks of age (Carbyn and Paquet, 2003). Arctic foxes at the den site at Kangowan River may therefore have had a stronger association with the den site than the wolves had, which may explain why the foxes expressed more aggressive behaviour than expected, given their size disadvantage. Note, however, that the outcome of interspecific interactions reported here might have been different if observations had been made when sharing of the den site was established, or if sharing of the den site had progressed further.

Smaller carnivore species occasionally kill the young of larger carnivore species (Palomares and Caro, 1999). However, arctic foxes at the den site at Kangowan River appeared to tolerate or avoid the unattended wolf pups. Similarly, wolves showed considerable tolerance towards adult foxes at the den site even though wolf pups were present. Again, we stress that we did not detect all interactions that occurred at this den site (see above). However, we suggest that avoidance and interspecific tolerance expressed by both foxes and wolves, on an occasion when interference interactions could be most intense, may have facilitated coexistence at this den site.

\section{ACKNOWLEDGEMENTS}

We thank J. Aitaok, B. Eyegetok, and D. Stern for assistance and hospitality in Cambridge Bay and three anonymous reviewers for their input on this manuscript. This study was funded by California Department of Fish and Game, Canadian Wildlife Service, Delta Waterfowl Foundation, Ducks Unlimited Inc., Polar Continental 
Shelf Project, Science Horizon Program, and University of Saskatchewan.

\section{REFERENCES}

AUDET, A.M., ROBBINS, C.B., and LARIVIÈRE, S. 2002. Alopex lagopus. Mammalian Species 713:1-10.

CARBYN, L.N., and PAQUET, P.C. 2003. Gray wolves. In: Feldhamer, G.A., Thompson, B.C., and Chapman, J.A. Wild mammals of North America: Biology, management, and conservation. 2nd ed. Baltimore, Maryland: John Hopkins University Press. 482-510.

KERBES, R.H. 1994. Colonies and numbers of Ross' geese and lesser snow geese in the Queen Maud Gulf Bird Sanctuary. Canadian Wildlife Service Occasional Paper 81. 45 p.

LINNELL, J.D.C., and STRAND, O. 2000. Interference interactions, co-existence and conservation of mammalian carnivores. Diversity and Distributions 6:169-176.
PALOMARES, F., and CARO, T.M. 1999. Interspecific killing among mammalian carnivores. American Naturalist 154: 492-508.

PETERSON, R.O. 1995. Wolves as interspecific competitors in canid ecology. In: Carbyn, L.N., Fritts, S.H., and Seip, D.R., eds. Ecology and conservation of wolves in a changing world. Edmonton, Alberta: Canadian Circumpolar Institute. 315 - 324.

RYDER, J.P. 1972. Biology of nesting Ross's geese. Ardea 60: $185-215$.

SARGEANT, A.B., and ALLEN, S.H. 1989. Observed interactions between coyotes and red foxes. Journal of Mammalogy 70: $631-633$.

SARGEANT, A.B., ALLEN, S.H., and HASTINGS, J.O. 1987. Spatial relations between sympatric coyotes and red foxes in North Dakota. Journal of Wildlife Management 51:285-293.

TANNERFELDT, M., ELMHAGEN, B., and ANGERBJÖRN, A. 2002. Exclusion by interference competition? The relationship between red and arctic foxes. Oecologia 132:213-220.

VOIGT, D.R., and EARLE, B.D. 1983. Avoidance of coyotes by red fox families. Journal of Wildlife Management 47:852 -857. 